\title{
Hak dan Kewajiban Warga Negara Mendapatkan Vaksinasi Covid-19
}

\author{
Alfara Derista Felany \\ Institut IImu Kesehatan Strada Indonesia \\ alfaraderista05@gmail.com
}

\begin{abstract}
Abstrak
Pandemi covid-19 menimbulkan status kedaruratan di Indonesia. Berbagai upaya dilakukan dalam rangka mengatasi dampak pandemi covid-19. Salah satunya adalah upaya vaksinasi. Program vaksinasi nasional untuk penanggulangan Covid-19 sedang gencar dilakukan pemerintah sejak Januari 2021. Tindakan ini merupakan wujud pemenuhan kewajiban negara untuk memenuhi dan melindungi hak atas kesehatan rakyat. Proses penerapan vaksinasi harus dikawal berbagai pihak dan menjadi perhatian bersama agar tidak melanggar prinsip hak asasi manusia.
\end{abstract}

\section{Latar Belakang}

Pada tanggal 31 Desember 2019, dilaporkan terdapat 27 kasus pneumonia dengan etiologi yang tidak diketahui di Kota Wuhan, provinsi Hubei di Cina. Pada 30 Januari 2020, WHO mendeklarasikan wabah COVID-19 di Cina sebagai Kedaruratan Kesehatan Masyarakat yang Meresahkan Dunia (Public Health Emergency of International Concern,PHEIC) ini menandakan COVID-19 sebagai ancaman global dunia dan menimbulkan berbagai kedaruratan diberbagai dunia, salah satunya di Indonesia. The emergency committee telah menyatakan bahwa penyebaran COVID-19 dapat dihentikan jika dilakukan proteksi, deteksi dini, isolasi, dan perawatan yang cepat agar tercipta implementasi sistem yang kuat untuk menghentikan penyebaran COVID-19. Mengingat hal ini, sebagai upaya proteksi terhadap COVID-19, berbagai negara dari seluruh dunia telah berkomitmen bersama dengan melibatkan pemerintah, perusahaan bioteknologi, ilmuwan, dan akademisi untuk dapat menciptakan vaksin Covid19. Pada perkembangan penanganan covid-19 di berbagai dunia, terdapat sejumlah merek vaksin dalam rangka penanganan covid-19 di Indonesia.

Rinciannya adalah 3 juta dosis yang sudah tiba di tanah air (per 6 Januari 2021) ditambah 122,5 juta dosis lagi dari Sinovac, kemudian dari Novavax sebanyak itu 50 juta 
dosis, dari COVAX/Gavi sejumlah 54 juta odsis, dari Astrazeneca 50 juta dosis dan dari pfizer sejumlah 50 juta dosis vaksin. Total vaksin yang dipesan adalah 329.5 juta dosis vaksin covid-19. Akan tetapi di tingkat masyarakat terjadi pro dan kontra terkait pelaksanaan vaksinasi di Indonesia sejumlah pihak mempertanyakan apakah vaksinasi untuk masyarakat merupakan hak ataukah kewajiban pemerintah melalui wakil menteri hukum dan hak asasi manusia menyampaikan bahwa vaksinasi covid 19 merupakan bagian dari kewajiban seluruh warga negara untuk mewujudkan kesehatan masyarakat.

\section{Kasus / masalah}

1) Bagaimana upaya pemerintah dalam menghadapi penyebaran virus covid-19?

2) Bagaimana hak dan kewajiban warga negara mendapatkan vaksinasi covid-19?

\section{Tinjauan Pustaka}

Menurut Prof. Dr. Notonegoro. Beliau mengungkapkan bahwa hak adalah sebuah kuasa untuk menerima atau melakukan suatu hal yang memang semestinya diterima atau dilakukan. Dalam hal ini, tidak bisa dilakukan atau diterima oleh pihak yang lain. Prof. Dr. Notogeoro menyatakan kewajiban sebagai sebuah beban memberikan suatu hal yang sudah semestinya diberikan oleh pihak tertentu. Dalam hal ini tidak bisa diberikan oleh pihak yang lain dan sifatnya bisa dituntut secara paksa jika tidak dipenuhi. Kewajiban juga diartikan sebagai suatu hal yang harus dilakukan.

Menurut WHO (2020a), penyakit coronavirus disease 2019 (COVID-19) adalah penyakit menular yang disebabkan oleh virus corona yang baru ditemukan. Kebanyakan orang yang terinfeksi virus COVID-19 akan mengalami penyakit pernapasan ringan hingga sedang dan sembuh tanpa memerlukan perawatan khusus. Orang tua dan orang-orang yang memiliki komorbit seperti penyakit kardiovaskular, diabetes, penyakit pernapasan kronis, dan kanker memungkin tertular COVID-19. Coronavirus disease 2019 (COVID-19) adalah penyakit yang disebabkan oleh turunan coronavirus baru. 'CO' diambil dari corona, 'VI' virus, dan 'D' disease (penyakit). Sebelumnya, penyakit ini disebut '2019 novel coronavirus' atau '2019nCoV.' Virus COVID-19 adalah virus baru yang terkait dengan keluarga virus yang sama dengan Severe Acute Respiratory Syndrome (SARS) dan beberapa jenis virus flu biasa (UNICEF, 2020). Menurut Sun et al., 2020, COVID-19 adalah penyakit coronavirus zoonosis ketiga yang diketahui setelah SARS dan sindrom pernapasan Timur Tengah (MERS). 
Menurut pakar penyakit menular asal Amerika Serikat, Dr.Faheem Younus MD. menyatakan bahwa vaksin Covid-19 sudah terbukti dapat melindungi diri dari paparan virus Covid-19.

Menurut Dr. Faheeem, vaksin Covid-19 bukanlah suatu hal yang harus ditakuti karena vaksin Covid-19 cenderung aman dan bahkan aman untuk orang yang memiliki alergi makanan hingga ibu hamil.

\section{Pembahasan}

\section{1) Upaya pemerintah dalam menghadapi penyebaran virus covid-19}

Pemerintah Pusat melalui Gugus Tugas Percepatan Penanganan COVID-19 membuat empat strategi yang akan secara konsisten dilakukan untuk menguatkan kebijakan physical distancing sebagai strategi dasar demi mengatasi pandemi Virus Corona COVID-19.Juru bicara Gugus Tugas Percepatan Penanggulangan COVID-19 Ahmad Yurianto, mengungkapkan strategi pertama sebagai penguatan strategi dasar itu adalah dengan gerakan masker untuk semua yang mengampanyekan kewajiban memakai masker saat berada di ruang publik atau di luar rumah. Strategi kedua, lanjut Yuri, adalah penelusuran kontak (tracing) dari kasus positif yang dirawat dengan menggunakan rapid test atau tes cepat. Di antaranya adalah pada orang terdekat, tenaga kesehatan yang merawat pasien COVID-19, serta pada masyarakat di daerah yang ditemukan kasus banyak. Strategi ketiga adalah edukasi dan penyiapan isolasi secara mandiri pada sebagian hasil tracing yang menunjukan hasil tes positif dari rapid tes atau negatif dengan gejala untuk melakukan isolasi mandiri. Strategi keempat adalah isolasi Rumah Sakit yang dilakukan kala isolasi mandiri tidak mungkin dilakukan, seperti karena ada tanda klinis yang butuh layanan definitif di Rumah Sakit.

Optimisme mulai terdengar ketika Pemerintah mulai berupaya untuk mendatangkan vaksin dari beberapa negara untuk mengatasi masalah COVID-19. Negara berupaya untuk mengelola vaksinasi mulai dari pendanaan, pengadaan dan distribusi termasuk hubungan dan elaborasi antar Kementerian dan Lembaga, yang dilakukan secara komprehensif. Upaya untuk mendatangkan vaksin telah dilakukan oleh Menteri Kesehatan RI bersama-sama dengan Menko Maritim dan 
Investasi, Menteri Luar Negeri dan Menteri BUMN sehingga Indonesia mendapatkan akses terhadap kandidat vaksin Sinovac (RRT), Sinopharm (RRT) dan Astra Zeneca (Inggris). Selain mekanisme kerja sama bilateral, dalam mencari sumber-sumber vaksin, Pemerintah juga menggandeng organisasi/aliansi internasional, yaitu Coalition for Epidemic Preparedness Innovations (CEPI) dan Global Alliance for Vaccine and Immunization (GAVI). Di Indonesia sendiri, para Peneliti Indonesia juga sedang mengembangkan Vaksin Merah Putih dengan menggunakan strain virus Indonesia.

\section{2) Hak dan kewajiban warga negara mendapatkan vaksinasi covid-19}

Kesehatan menjadi salah satu kebutuhan dasar manusia. Pengakuan dan perlindungan hak atas kesehatan tersebut diatur secara konstitusional. Sejak masa berlakunya Konstitusi Republik Serikat, hak atas kesehatan telah diatur pada pasal 40 yang berbunyi sebagai berikut: "Penguasa senantiasa berusaha dengan sungguh-sungguh memajukan kebersihan umum dan kesehatan rakyat." Pengaturan hak atas kesehatan pada pasal 40 Konstitusi Republik Indonesia Serikat tersebut kemudian di adopsi oleh Pasal 42 Undang-Undang Dasar Sementara (UUDS).15 Kemudian setelah berlakunya UUD NRI Tahun 1945, hak atas kesehatan16 kembali diatur pada Pasal $28 \mathrm{H}$ ayat (1) dengan norma sebagai berikut: “...setiap orang berhak hidup sejahtera lahir dan batin, bertempat tinggal, dan mendapatkan lingkungan hidup yang baik dan sehat serta berhak memperoleh pelayanan kesehatan...". Sebagai atribut ketentuan tersebut Pasal 4 UndangUndang Nomor 36 Tahun 2009 tentang Kesehatan menyatakan bahwa

"Setiap orang berhak atas kesehatan" secara garis besar Undang-Undang kesehatan dan UUD 1945 mengisyaratkan bahwa setiap individu, keluarga dan masyarakat berhak memperoleh perlindungan terhadap kesehatannya, dan negara bertanggung jawab mengatur agar terpenuhi hak hidup sehat bagi penduduknya termasuk bagi masyarakat miskin dan tidak mampu. Masuknya ketentuan tersebut ke dalam Undang- Undang Dasar 1945 dan Undang-Undang Kesehatan, menggambarkan perubahan paradigma yang luar biasa. Kesehatan tidak lagi hanya dikaitkan dengan nasib atau karunia Tuhan yang menjadi urusan pribadi setiap orang dan sama sekali tidak ada hubungannya dengan tanggung jawab negara, namun saat ini kesehatan telah menjadi suatu hak hukum (legal rights) yang dijamin, dilindungi, dihormati dan harus dipenuhi oleh negara. Hal tersebut sangat jelas tercermin kembali pada pasal 28I ayat (4) UUD 1945 yang 
menegaskan bahwa Perlindungan, pemajuan, penegakan, dan pemenuhan hak asasi manusia adalah tanggung jawab negara, terutama pemerintah.

Mempertanyakan vaksinasi sebagai hak atau kewaiban lebih ditekankan pada bagaimana pemerintah di suatu negara mengambil kebijakan atas vaksin sebagai upaya untuk menekan penyebaran covid-19. Bagi Indonesia, pemerintah telah tegas menyatakan bahwa vaksin merupakan kewajiban bagi pemerintah untuk diberikan kepaa warganya sebagai hak agar tetap sehat dan aman dari kemungkinan infeksi virus corona.

\section{Kesimpulan}

Berdasarkan pembahasan diatas, maka dapat disimpulkan bahwa vaksinasi dalam rangka penanganan covid-19 adalah suatu hak sekaligus kewajiban dari warga negara, terdapat hak seseorang untuk memilih pelayanan kesehatan baginya. namun bila dilihat dari konteks virus covid-19 yang berskala pandemi, bahwa seseorang yang tidak divaksin justru dapat berpotensi menjadi virus carrier bagi orang lain, maka hak tersebut dapat dikurangi dalam rangka untuk mencapai tujuan negara yakni melindungi segenap bangsa Indonesia dan seluruh tumpah darah Indonesia (dalam hal ini, melindungi dari virus covid19), dan juga termasuk melindungi hak asasi seseorang itu sendiri dalam rangka memperoleh hak untuk hidup secara sehat. Oleh sebab itu, vaksinasi yang pada mulanya adalah suatu hak bagi seseorang dapat berubah menjadi di suatu kewajiban mengingat negara dalam keadaan darurat dan selanjutnya adalah berkaitan dengan kewajiban asasi orang lain, dalam hal ini adalah hak atas kesehatan orang lain. Dan Pemerintah memiliki kewajiban untuk menyediakan layanan kesehatan bagi seluruh masyarakat. Hal ini menjadi poin penting bahwa kesehatan publik merupakan bagian dari hak asasi yang wajib dilindungi.

\section{Daftar Pustaka}

Buku :

Siyoto, S., \& Sodik, M. A. (2015). Dasar metodologi penelitian. Literasi Media Publishing.

Jurnal :

Handayani, Rina Tri. et. al. "Pandemi Covid-19, Respon Imun Tubuh, Dan Herd Immunity," jurnal ilmiah Permas, Sekolah Tinggi IImu Kesehatan Kendal, Volume 10 No.3 (2020) 
Rif 'atul Hidayat, Hak Atas Derajat Pelayanan Kesehatan Yang Optimal, SYARIAH Jurnal Hukum dan Pemikiran, Volume 16, Nomor 2, Desember, Tahun 2016

Siti Nurhalimah, Covid-19 dan Hak Masyarakat atas Kesehatan, SALAM; Jurnal Sosial \& Budaya Syar-i, FSH UIN Syarif Hidayatullah Jakarta Vol. 7 No. 6 (2020)

Website :

SatgasCovid-19, "Empat Strategi Pemerintah Atasi Covid-19," siaran pers 08 April 2020, dikutip dari laman resmi gugus tugas covid-19 https://covid19.go.id/p/berita/empatstrategi-pemerintah-atasi-covid-19 